\title{
Slope Processes, Mass Movements and Soil Erosion: A Review
}

\author{
Antônio José Teixeira GUERRA*¹, Michael Augustine FULLEN ${ }^{2}$, Maria do Carmo Oliveira \\ JORGE $^{1}$ and José Fernando Rodrigues BEZERRA ${ }^{3}$ \\ ${ }^{1}$ Department of Geography, Federal University of Rio de Janeiro, Brazil. \\ ${ }^{2}$ Faculty of Science and Engineering, University of Wolverhampton, UK. \\ ${ }^{3}$ Department de Geography, State University of Maranhão, Brazil.
}

\begin{abstract}
This paper reviews slope processes associated with mass movements and soil erosion and contributory factors, including physical and human agents. Acting together, these cause diverse geomorphological features. Slope processes are illustrated by reference to case studies from Brazil and the UK. The causes and impacts of erosion are discussed, along with appropriate remedial bioengineering methods and the potential of measures to prevent these types of environmental degradation.
\end{abstract}

Key Words: Mass movements, soil erosion, land degradation, hazards, risks, soil recuperation.

\section{INTRODUCTION}

This article reviews the dominant hillslope processes associated with gravity and running water. Human activity plays important roles in hillslope processes, due to land use changes and vegetation clearance, both in rural and urban areas. These processes can be accentuated by climate change (Varnes, 1978; Trudgill, 1988; Selby, 1993; Goudie, 1995; Cendrero and Dramis, 1996; Cruden and Varnes, 1996; Goudie and Viles, 1997; Favis-Mortlock and Guerra, 1999; Fullen, 2003; Fullen and Catt, 2004; Crozier and Glade, 2005; VanWesten et al., 2008; Arbuckle, 2013; Kanungo and Sharmas, 2014; Shafiq et al., 2014; Agnihotri and Kumar, 2015). The causes and consequences of both sets of processes are discussed. Furthermore, the importance of monitoring these processes is considered, in order to understand how they occur and can be prevented (Lascelles et al., 2000; Valentin et al., 2005; Bochet et al., 2006; Kitutu et al., 2007; Nadal-Romero et al., 2014; Vanmaercke et al., 2016). In addition, once they do occur, we consider potential recuperation technologies (Fullen et al., 1995; Fullen and Catt, 2004; Subedi et al., 2009; Bhattacharyya et al., 2010, 2011; De Baets et al., 2011; Fullen et al., 2011; Subedi et al., 2012; Dhital et al., 2013; Guerra et al., 2015).

Proactive management of vegetation systems are essential for effective recuperation (Trudgill, 1988; Fullen and Catt, 2004; De Baets et al., 2011; Fullen et al., 2011; Bhattacharyya et al., 2012; Dhital et al., 2013; Guerra et al., 2015). The role of soil erosion is discussed, considering 
accelerated erosion as one of the greatest problems of land degradation, because it seriously depletes fertile topsoil. The removal of original vegetation for agricultural purposes is one of the main factors causing soil erosion. The general forms of soil erosion by water (including sheet, rill and gully erosion) are discussed and illustrated using Brazilian and British field examples.

A detailed description of the main geo-environmental features of a region and its different effects on the occurrence of landslides and soil erosion is presented. To reach this objective, several factors have been addressed, and are illustrated using examples from Brazil and the UK. Geomorphic activity is usually a critical determinant of damage. Each of the two geomorphic processes analysed in this article have specific causal factors, such as vegetation clearance, rainfall intensity, rainfall volume, slope angle, soil properties, land use and land management, which affect soil erosion and mass movements, both in urban and rural areas. Depending on the frequency and magnitude of each one of these factors, catastrophic landslides might occur, and some examples are discussed.

The role of mass movements and associated geomorphological processes are discussed, along with the diagnostic parameters to recognize different types of mass movement in the field (Varnes, 1978; Brunsden, 1988; Goudie and Viles, 1997; Crozier and Glade, 2005; Morgan, 2005; Lin et al., 2006; VanWesten et al., 2008; Eeckhaut et al., 2010; Clague and Robert, 2012; Guzzetti et al., 2012; Kanungo and Sharmas, 2014). Again, Brazilian and British examples are used to illustrate these features (Selby, 1993; Goudie and Viles, 1997; Fullen and Catt, 2004; Coelho Netto et al., 2007; Guerra et al., 2007; Graeff et al., 2012; Petruci et al., 2013; Guerra and Jorge, 2014).

Selby (1993) outlined that mass movements (or 'mass wasting') is the movement of soil and/or rock downslope, under the influence of gravity, being a collective material movement, without necessarily being influenced by water or ice. Nevertheless, water or ice may decrease the shear strength of slopes, thus soils physically behave as plastics or, in very moist conditions, as fluids (Abrahams, 1986; Brunsden, 1988; Selby, 1993; Goudie and Viles, 1997; Clague and Robert, 2012; Kanungo and Sharmas, 2014; Guerra and Jorge, 2014). This might, consequently, make mass movements even more catastrophic, causing destruction and even mortalities.

Soil erosion and land degradation are global problems and pose major issues in many countries, including Brazil. The hazards affect both urban and rural areas within the extensive national territory $\left(8,547,403 \mathrm{~km}^{2}\right)$. In turn, these problems have serious environmental and socio-economic impacts (Guerra et al., 2014). It is important that soils be conserved, for present and future generations. Although erosion is a natural phenomenon, often human activity accelerates erosion processes. Erosion may occur naturally, due to slope angle and rainfall. Some surveys exemplify this, often based on stratigraphical and archaeological evidence within valley floor deposits. For instance, natural soil erosion has been reconstructed in North Germany from the early Holocene, when soil developed under natural woodlands, up to the early Middle Ages, when erosion rates were still very low (Bork, 1989). Furthermore, Dotterweich (2009) and Dreibrodt et al. (2010) have discussed soil erosion during the Holocene. During the Neolithic ( 7,500 years BP) "many areas of central European soil has been washed downslope by soil erosion and gullies have incised, leading to the development of colluvial and alluvial deposits" (Dotterweich, 2009). Soil erosion on US agricultural soils causes the loss of an average of 30 tonnes per hectare per year; some eight times greater than rates of soil formation. A survey by EMBRAPA (Brazilian Agricultural Research Corporation) suggested the situation in Brazil is often worse, reaching 60 tonnes per hectare per year in south-eastern Brazil (EMBRAPA, 2002). According to Goudie and Boardman (2010) "it is quite clear that the major areas of intense erosion are associated with both human and natural 
factors." Boardman (2006) suggested the following countries and regions are global erosion 'hotspots:' the Loess Plateau of China, Ethiopia, Swaziland and Lesotho, the Andes, South and East Asia, the Mediterranean basin, Iceland, Madagascar, the Himalayas, the Sahel of West Africa, the Caribbean and Central America. We propose Brazil is also an erosion 'hotspot' (Silva et al., 2005; Gurgel et al., 2013; Guerra et al., 2014; Nacinovic et al., 2014).

Although both soil erosion and mass movements are two forms of land degradation, and humans play important roles in these geomorphological processes, they present different modes of occurrence and consequently different ways of being identified, monitored and they present diverse features (Varnes, 1978; Small and Clark, 1982; Abrahams, 1986; Brunsden, 1988; Gerrard, 1992; Evans, 1993; Selby, 1993; Guerra, 1994; Goudie and Viles, 1997; Favis-Mortlock and Guerra, 1999; Fullen and Catt, 2004; Crozier and Glade, 2005; Morgan, 2005; Lin et al., 2006; Van Beek et al.,

2008; VanWesten et al., 2008; Goudie and Boardman, 2010; Vente et al., 2011; Boardman and Favis-Mortlock, 2013; Kanungo and Sharmas, 2014; Oluwagbenga and Orimoogunje, 2014; Guerra et al., 2015; Monsieurs et al., 2015; Vanmaercke et al., 2016). Nevertheless, the best way to avoid both forms of land degradation is acting preventively, that means to understand the risks of soil erosion and/or mass movements, in order to avoid them. In this respect, Oluwagbenga and Orimoogunje (2014) stated that "conservationism emphasizes the need to guarantee a sustainable supply of productive land resource for future generations. Preservationism seeks to protect scenery and ecosystems in a state as little affected by humans as possible."

\section{MATERIALS AND METHODS}

Firstly, an extensive literature survey of over 100 publications was completed. Studied aspects included soil erosion, including soil erodibility, erosivity, soil properties, soil types, slope angle, length and shape, vegetation cover, vegetation clearance, climate change and land use and management. Climate regime plays an important role for both soil erosion and mass movements. With regard to rainfall, over a long period, most erosion occurs during events of moderate frequency and magnitude, because catastrophic events are not so frequent so as to cause a great amount of net erosion. This this is a short-term perspective; when high magnitude events occur soil loss is much higher than during moderate rainfalls; heavy precipitation events are the main reason for the incision of gullies in many landscapes (Dreibrodt and Wiethold, 2015). The same applies to mass movements, taking into account the main factors, which affect this geomorphological process (i.e. slope angle and shape, soil properties, vegetation cover, soil depth, the interface between soil and the underlying rock, vegetation clearance, human factors, such as slope talus cuts, lack of soil drainage and sewage and unpaved roads). "At a long temporal scale, the relationship between landslide activity and triggering mechanisms can be established from the temporal clustering of dated landslides" (Borgatti and Soldati, 2010). The comprehensive literature survey article is based on articles, mainly from 2000-2015, but also some pre-2000 literature.

\section{DISCUSSION}

\section{Mass movements}

Soil erosion and mass movements have attracted thousands of studies across the world. Although both processes constitute forms of land degradation, for this review article we describe 
them separately. Selby (1993) concisely described mass movements, or "mass wasting of soils" as the movement of soil and/or rock, downslope, under gravity, of collective materials, without necessarily water or ice action. Varnes (1978) developed a mass movement classification based on the material (mud, soil, earth, rock and debris) and movement type (falls, topples, slides (rotational and translational), lateral spreads and flows). Varnes also proposed a further type, which he named 'complex,' which is a combination of two or more principal types of movement. These movements are outlined in this article, and some examples are presented. When there is the action of water and/or ice, the agents may decrease soil shear strength and, consequently, contribute to the plastic or liquid behaviour of soil, making mass movements even more catastrophic (Varnes, 1978; Brunsden, 1988; Goudie, 1995; Cendrero and Dramis, 1996; Goudie and Viles, 1997; Crozier and Glade, 2005; Van Beek et al., 2008; VanWesten et al., 2008; Fell et al., 2012; Graeff et al., 2012; Korup, 2012; Petruci et al., 2013; Guerra and Jorge, 2014; Kanungo and Sharmas, 2014). Surveys of mass movements have different aims, including predicting their occurrence, which depends on several factors. Therefore, "care is required with the interpretation of site characteristics. Undoubtedly, any judgement, on mass movement hazards will be subjective and it is strongly advised that local expertise is consulted, as distinct conditions may be important for the initiation and reactivation of mass movement in a given region" (Van Beek et al., 2008). Therefore, the geomorphological investigation of mass movements may provide a framework, in order to describe and map surface landslide processes, and to predict future process behaviour (Brunsden, 1988; Selby, 1993; Griffiths and Whitworth, 2012; Kanungo and Sharmas, 2014). Guzzetti et al. (2012) recommended that "to prepare a landslide map, a legend is required. The legend must meet the project goals, must be capable of portraying relevant geomorphological characteristics, and must be compatible with the technique used to capture the information."

Several authors have monitored mass movement dynamics (Goudie, 1995). In this respect, Petley (1984) described the main objectives of surveys of mass movements:

1. To understand the development of natural slopes and the processes that contribute to the formation of new features.

2. To make it possible to stabilize slopes under different conditions.

3. To determine landslide risk, or other forms of mass movements, including on natural and artificial slopes.

4. To facilitate recuperation on slopes which have experienced mass movements and to plan land-uses which include preventive measures, so that those geomorphological processes do not recur.

5. To analyse the various types of mass movements and assess the causes and consequences of these processes.

6. To know how to respond to external factors influencing slope stability, such as earthquakes, which also play important roles in triggering mass movements.

Many authors have addressed the important issues of mass movement hazard and risk. Crozier and Glade (2005) highlighted that the level of risk is the combination of the likelihood of adverse occurrences and the consequences if it does. The level of risk results from the intersection of hazard with the value of the elements at risk by way of their vulnerability.

There are different types of mass movement. Therefore, the different definitions used and the physical principles which underlie mass movements must be explained and the diagnostic parameters to explain how to recognize different types of mass movements in the field are fundamental. The main types of mass movement are falls, slides and flows (Varnes, 1978; Brunsden, 
1988; Selby, 1993; Van Beek et al., 2008; Clague and Robert, 2012). They have many causes, including deforestation, adverse hydrological conditions and slope undercutting, climate (precipitation/thawing of ice), geology (water impermeable layers and swelling clays), earthquakes and volcanic eruptions. In addition, meteorological events, such as heavy rainstorms, inducing water infiltration and increased pore water pressure; and increased air temperatures, inducing the melting of glacial or ground ice (Cendrero and Dramis, 1996).

The most common and catastrophic mass movements are landslides. According to Clague and Robert (2012) "each year, landslides are responsible for hundreds of millions of dollars' worth of damage and, on average, claim more than 1,000 lives around the world. Although most common in mountainous areas, landslides can occur anywhere with enough local relief to generate gravitational stresses capable of causing rock or soil to fail” (Figs. 1 and 2). They may be one of the most damaging and deadly of the natural hazards in the world, and the data available from the 'Centre for Research on the Epidemiology of Disasters' (CRED), located in Leuven, Belgium, suggest that landslides were responsible for over 10,000 deaths and left 2.5 million people homeless between 2001-2010 (CRED, 2011). Another useful definition of landslides is proposed by Korup (2012), who stated "landslides are the downhill and outward movement of slope-forming materials under the influence of gravity and also, in most cases, water. Mostly triggered by earthquakes, rainstorms, snowmelt, and slope undercutting, they are among the prime producers of sediment and major agents of denudation." In fact, although there are different types of mass movement, it is very common amongst many authors view landslides as synonymous with mass movements.

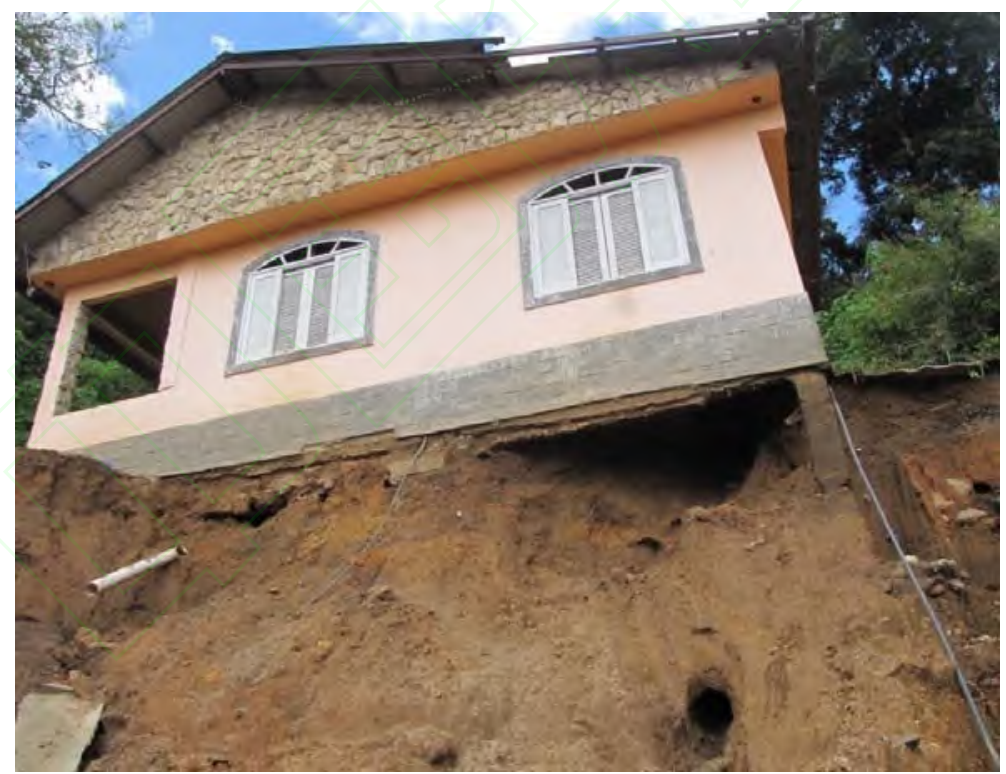

Fig. 1 A landslide scar formed due to heavy rainstorms in April 2013 in Petrópolis Municipality, Brazil. The house was condemned on safety grounds (photo by Antonio Jose Teixeira Guerra). 


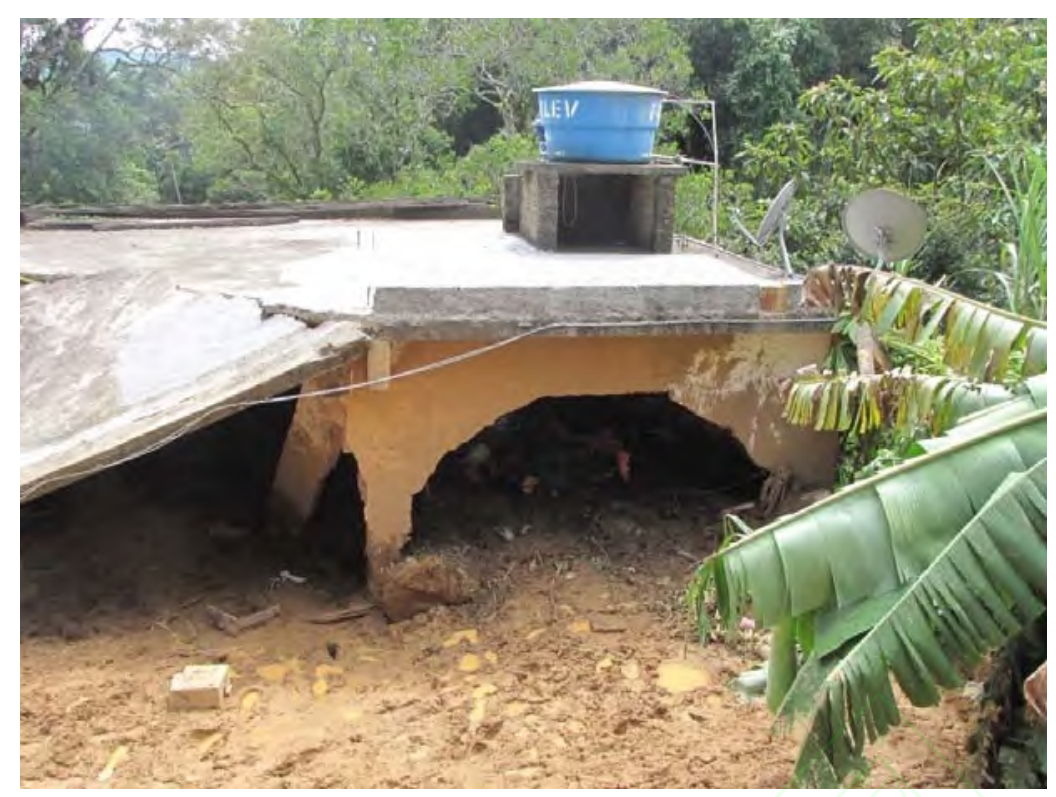

Fig. 2 House destroyed by a landslide in April 2013 in Petrópolis Municipality. This caused the death of three people (photo by Antonio Jose Teixeira Guerra).

Mass movements have been surveyed by many disciplines, including geologists, geomorphologists and engineers. They have used different approaches, but all of them are concerned with understanding the processes, in order to be able to propose ways to assess and, consequently, to avoid them (Morgan, 2005). The amount of sediments transported by mass movements to rivers is much greater than that transported by rills and gullies (Morgan, 2005). It is extremely important to predict mass movements. An initial step is to construct accurate and reliable maps that can be used to assist the prediction of landslide hazards and risks in a specific area. It is crucial to have insights into the spatial and temporal frequency of landslides, and therefore each landslide hazard or risk study should start by making a landslide inventory that is as complete as possible, both in space and time (VanWesten et al., 2008). Consequently, by mapping and dating the phenomena present in the landscape, we become able to: a) outline hazardous zones (mapping and comparison with geological and relief data), and b) consider recurrence intervals and relevant processes (such as dating and comparison with palaeoclimatic data, palaeovegetation data and historical land use data).

In a survey in Ubatuba Municipality (São Paulo State, Brazil) deforested steep slopes were the necessary preconditions for mass movements, which were then triggered by heavy rainstorms (Guerra and Oliveira, 2009). In Ubatuba, these natural conditions can be accentuated by unplanned settlements. Urban expansion was accelerated after the construction of the Rio-Santos Highway, attracting many tourists to this area and, consequently, promoting rapid construction of houses and resort buildings, without respecting environmental risks (Fig. 3).

House construction has tended to move beyond the densely settled coastal plains onto adjacent hillslopes, which are often steep. This poses problems to both residents and tourists (Souza and Suguio, 2003; Ferreira et al., 2005; Guerra and Oliveira, 2009; Mendes and Valerio Filho, 2015). Ubatuba is infamous for landslides. "In general, the major natural constrains that are responsible for translational landslides in the study area include high slope steepness (usually over $30^{\circ}$ ), which is associated with morphology (concave and/or linear geometry), and the presence of seasonal "apparent" cohesion, which results from saturated soil profiles and high rainfall (cumulative and/or hourly rainfall intensity)" (Mendes and Valerio Filho, 2015). 


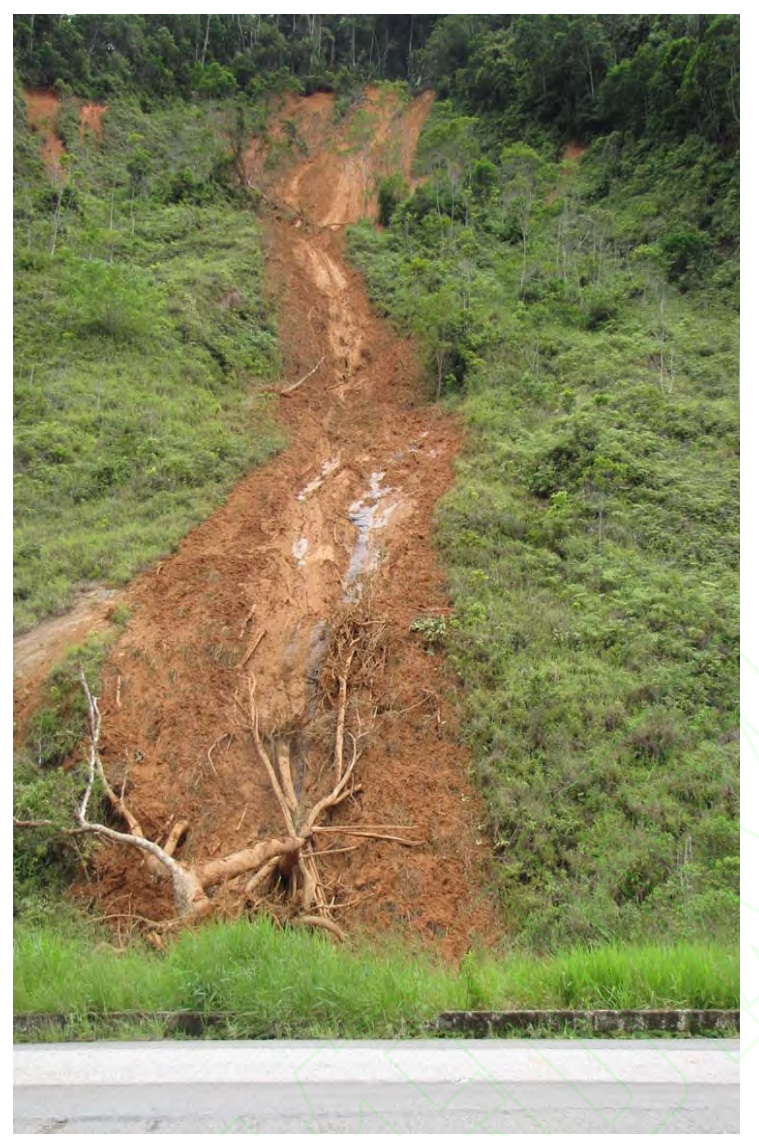

Fig. 3 Shallow landslide scar on Rio-Santos Highway, in Ubatuba Municipality, São Paulo State, Brazil, December 2009 (photo by Maria do Carmo Oliveira Jorge).

Guerra et al. (2007) conducted a comparable survey and analysed mass movements in Petrópolis Municipality, where 50 people died in 2001, due to landslides caused by 200 mm of rain in 24 hours. In 2011 another heavy rainfall of $240 \mathrm{~mm}$ in 24 hours caused landslides that resulted in the deaths of 71 people in the same Municipality (Graeff et al., 2012). In both surveys, the authors arrived at very similar conclusions. The main causes of these catastrophic geomorphological processes were both natural (i.e. heavy rainstorms and steep slopes) and human factors (i.e. unplanned settlement, vegetation clearance, unpaved roads and lack of appropriate sewage systems and rain-water conduits). These findings agree with Trudgill (1988), who outlined that mass movements can be seen from the perspective of their relationships between natural components and responses to slope perturbations. Trudgill (1988) identified that mass movements usually start with vegetation clearance, although in some cases they might occur on vegetated slopes. Furthermore, soil and vegetation systems are complex, and one of the main associated problems is the application of the stability concept. Some subcomponents of the system will experience more changes than others (Brunsden, 1988; Gerrard, 1992; Selby, 1993; Goudie and Viles, 1997; Morgan, 2005; Van Beek et al., 2008; Clague and Robert, 2012; Fell et al., 2012; Korup, 2012; Brunetti et al., 2014).

The Rio de Janeiro-Ubatuba Highway, which connects Rio de Janeiro and São Paulo States, has attracted many people, who often build their houses on steep slopes. This type of urban settlement on these steep slopes has been responsible for many landslides, especially in recent years (Fig. 4). They have caused the death of dozens of people and severe material losses (Ferreira et al., 2005; Guerra and Jorge, 2009; Guerra et al., 2013; Mendes and Valério Filho, 2015). 
Often there are time-lags between deforestation of steep slopes and the onset of mass movements. On forest clearance, tree roots remain largely intact and thus maintain slope stability. Roots can act as 'environmental nails' which retain soil in place. However, tree roots will undergo decomposition processes and these processes are usually rapid in the humid tropics. Thus, after about two years the 'environmental nail' effect is lost and slopes enter a precarious phase of potential instability (Goudie and Viles, 1997; Brunetti et al., 2014; Nadal-Romero et al., 2014).

The response of slopes to the different ways they are occupied depends on several factors, including the existing soils, slope angle, shape and human intervention. In recent decades in Brazil, and several other countries, there has been an increased frequency and magnitude of mass movements, partly due to physical environmental variables, but mainly due to the way constructions are built without taking into account the risks posed by the natural triggers at each site.

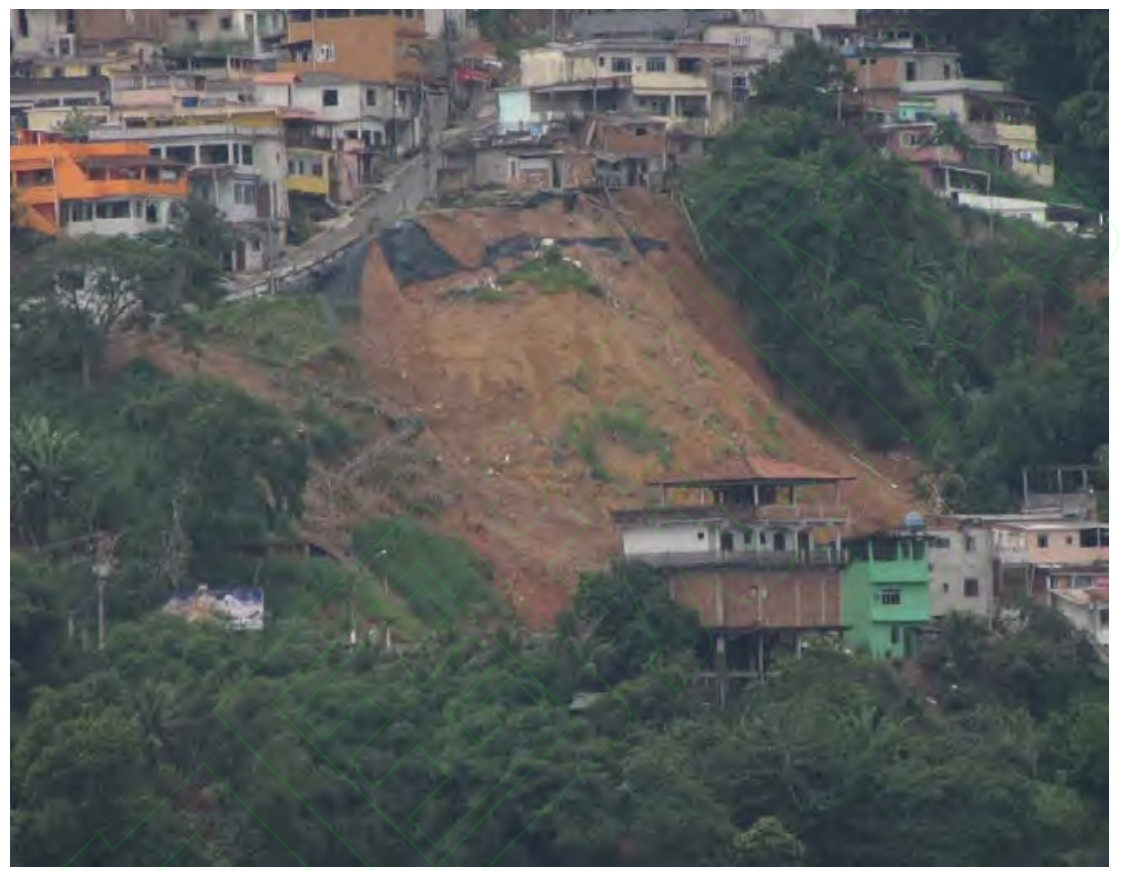

Fig. 4 Landslide scar in Angra dos Reis Municipality. During this event over 40 people died within the Municipality, due to landslides associated with $200 \mathrm{~mm}$ of rain in 24 hours, December 2009 (photo by Antonio Jose Teixeira Guerra).

Brunsden (1988) pointed out that planners need to know the risks to slopes, due to the kind of occupation. This is also emphasized by Small and Clark (1982), who outlined the role of humans when they alter the landscape, and they called this process the production of artificial slopes, which is particularly important on a local scale.

Local governments should obtain detailed information from scientists (geographers, geomorphologists, civil engineers, architects, planners, ecologists, soil scientists and geologists), in order to avoid the occurrence of mass movements, and consequently, loss of lives and property (Brunsden, 1988; Trudgill, 1988; Goudie and Viles, 1997; Guerra et al., 2007; Van Beek et al., 2008; Graeff et al., 2012; Guerra and Jorge, 2014; Fell et al., 2012; Korup, 2012). Furthermore, Brunsden (1988) stated that in cases of subsequent mass movements, local authorities should be responsible for authorizing the construction of roads and buildings. That is one of the reasons to produce environmental surveys, including slope assessment, before these areas are occupied, so that mass movement risks may be evaluated. In order to assess slope hazards and risks, it is also important to evaluate the rainfall threshold for landslides to occur. Therefore, Kanungo and 
Sharmas (2014) outlined that "a threshold may define the rainfall, soil moisture or hydrological conditions that when reached or exceeded, are likely to trigger landslides." This combination of environmental and human variables has to be taken into account, to predict mass movements and, therefore, try to avoid them.

\section{SOIL EROSION}

Selby (1993) classified soil erosion in his classic book 'Hillslope Materials and Processes' as a geomorphological process which occurs on hillslopes, carried out by flowing water and splash processes. Selby (1993) termed this "erosion on hillslopes by raindrops and flowing water." Selby outlined the role of water in removing and transporting sediments, which he described as "wash," a term adopted by many authors (Gerrard, 1992; Evans, 1993; Goudie and Viles, 1997; Poesen et al., 2006; Goudie and Boardman, 2010; Guerra et al., 2014).

It is important to outline the difference between 'natural soil erosion' and 'accelerated soil erosion.' The first one is what we can also call 'geological erosion,' which is water flowing on the soil surface, possibly transporting sediments and, consequently reducing soil thickness, but over a long period of time, and usually very slowly. In this case, weathering, which occurs on the rocks underneath the soil, can compensate for the eroded soil. Accelerated soil erosion usually occurs on agricultural fields and bare soils and depends on several factors, which are discussed in this paper. Therefore, other concepts may be introduced to differ natural and accelerated soil erosion; the first one is with respect to soil loss tolerance, and whether this exceeds a limit, causing land degradation, as rates of soil formation are usually much less than soil loss.

Sediments transported by running water usually pose another environmental problem; that is the off-site effects of soil erosion. This is becoming a recurrent problem in the UK, and therefore, Boardman and Vandaele (2010) outlined that "muddy flooding is caused by runoff carrying soil from bare or relatively bare agricultural fields." Documentation of muddy flooding exists for several other European countries, including Belgium, France, The Netherlands, Poland, Slovakia, Germany, Spain and Italy (Boardman and Vandaele, 2010). This is a good example of off-site effects from agricultural fields damaging property, roads and water bodies (rivers, reservoirs and lakes). Evrard et al. (2010) reported that in the European loess belt, water flowing from agricultural fields frequently carry large quantities of soil as suspended sediment. These geomorphological processes cause muddy floods in settlements downstream and are generally triggered on silty and loamy soils, which are prone to surface sealing (Boardman et al., 2006). Nevertheless, the best option is "in order to prevent (ephemeral) gullies from developing in cropland, all possible measures leading to an increase in rain infiltration, to a reduction in Hortonian overland flow discharge and hence also to a reduction of flow shear stress need to be applied" (Poesen et al., 2006). Consequently, there will be less risk of both on-site and off-site effects. In the European context, most concern is expressed over the damaging off-site effects of soil erosion on water quality and the costs associated with subsequent water purification for water supply systems (Fullen, 2003).

Soil erosion has different classifications, according to the region where it occurs, soil types, precipitation regime, soil properties, slope characteristics, land-use and management. Nevertheless, most authors agree that this process can cause three main features, depending on causal factors and on its evolution. These are sheet, rill and gully erosion (Abrahams, 1986; Selby, 1993; Goudie, 1995; Fullen and Catt, 2004; Morgan, 2005; Valentin et al., 2005; Boardman, 2006; Van Beek et al., 
2008; Goudie and Boardman, 2010; Vanmaercke et al., 2012; Monsieurs et al., 2015; Vanmaercke et al., 2016). Although the three erosion processes cause land degradation, wherever they occur "recent field-based studies indicate that: (1) gully erosion is an important soil degradation process in a range of European environments, causing considerable soil losses and producing large volumes of sediment, and (2) (ephemeral) gully development increases the sediment connectivity in the landscape and hence also the sediment delivery to lowlands and permanent water courses where gullies aggravate off-site effects of water erosion" (Poesen et al., 2006). This is another good example how off-site effects are usually at least as important as on-site effects in soil erosion surveys. Fullen and Catt (2004) outlined that when rainfall intensity exceeds soil infiltration capacity, runoff begins, thus provoking soil erosion. They also stated that the process initiates as sheet erosion, tending to concentrate in minor incisions, forming rills (Fig. 5), which may evolve into gullies (Figs. 6 and 7), as they widen and incise into the soil. Fullen and Catt (2004) admitted that this theme might be polemic. Therefore, they stated that while rills tend to incise mainly into the A horizon, gullies reach easily the B and even C horizons. Sometimes they even reach bedrock, depending on the magnitude of erosive processes. This is agreed by several authors (Thornes, 1990; Gerrard, 1992; Selby, 1993; Favis-Mortlock and Guerra, 1999; Morgan, 2005; Valentin et al., 2005; Boardman and Poesen, 2006; Evans, 2006; Goudie and Boardman, 2010; Guerra et al., 2014; Guerra et al., 2015; Labriere et al., 2015; Vanmaercke et al., 2016).

Surface runoff is produced due to several factors, including vegetation clearance, agriculture without conservation practises and rainfall regime. When rainfall intensity exceeds infiltration capacity, the excess rain forms surface runoff. This process causes sheet erosion, which might evolve into rill and gully erosion (Gerrard, 1992; Selby, 1993; Fullen and Catt, 2004; Morgan, 2005; Goudie and Boardman, 2010; Guerra et al., 2014; Labriere et al., 2015). As erosion processes at field level are dominated by concentrated rills, these linear erosion features can widen and deepen and cut into the subsoil, thus creating gullies. In addition, depending on the size of the agricultural fields, erosion may produce less soil loss, but the larger the fields, the larger the runoff collection in a catchment. As a result one has to consider different scales, both for surveying and for estimating damage. Enters (1998) reviewed this issue in detail, when he discussed scaling-up from fields to national levels. From this perspective, Enters (1998) outlined the on-site impacts of soil erosion, at several hierarchical scales, and occurrences at one scale usually influence outcomes at other scales. Furthermore, Izac and Swift (1994) defined five hierarchical levels for measuring soil erosion: cropping system, farming system, catchment system, regional system and supra-regional system.

Soil erosion is a natural phenomenon (i.e. it varies naturally with climate, soils and topography). Therefore, all landscapes which have slopes $>\sim 3^{\circ}$ may experience some form of erosion (Gerrard, 1992; Selby, 1993; Ashman and Puri, 2002; Fullen and Catt, 2004; Morgan 2005; Evans, 2006; Gumiere et al., 2009; Liu et al., 2014; Sensoy and Kara, 2014). Nevertheless, in Europe, during the Holocene, there was relatively little natural erosion once vegetation cover developed, except for early Holocene climate anomalies. According to Dreibrodt et al. (2010) "the general pattern is clearly reflected by the slope deposit record. At a closer look, there are different phases of variability within the record, and additional deposits are suspected to have been deposited during the Early Holocene." However, in some areas erosion and consequent deposition is fundamental for natural soil fertility maintenance, such as the Nile Delta, which receives sediments originating from Ethiopia. These natural processes have maintained soil fertility for centuries, but dam construction to control the Nile regime has disturbed this equilibrium (Ashman and Puri, 2002). Sediment from the Yellow River in northern China is also important for the maintenance of soil fertility on the 
adjacent floodplain (Fullen et al., 1995). Currently, synthetic fertilizers can maintain soil fertility, and river floods pose serious risks to people on the alluvial plain. The more crucial recent problem is shoreline erosion at the Nile Delta mouth, which can cause severe problems for coastal settlements.

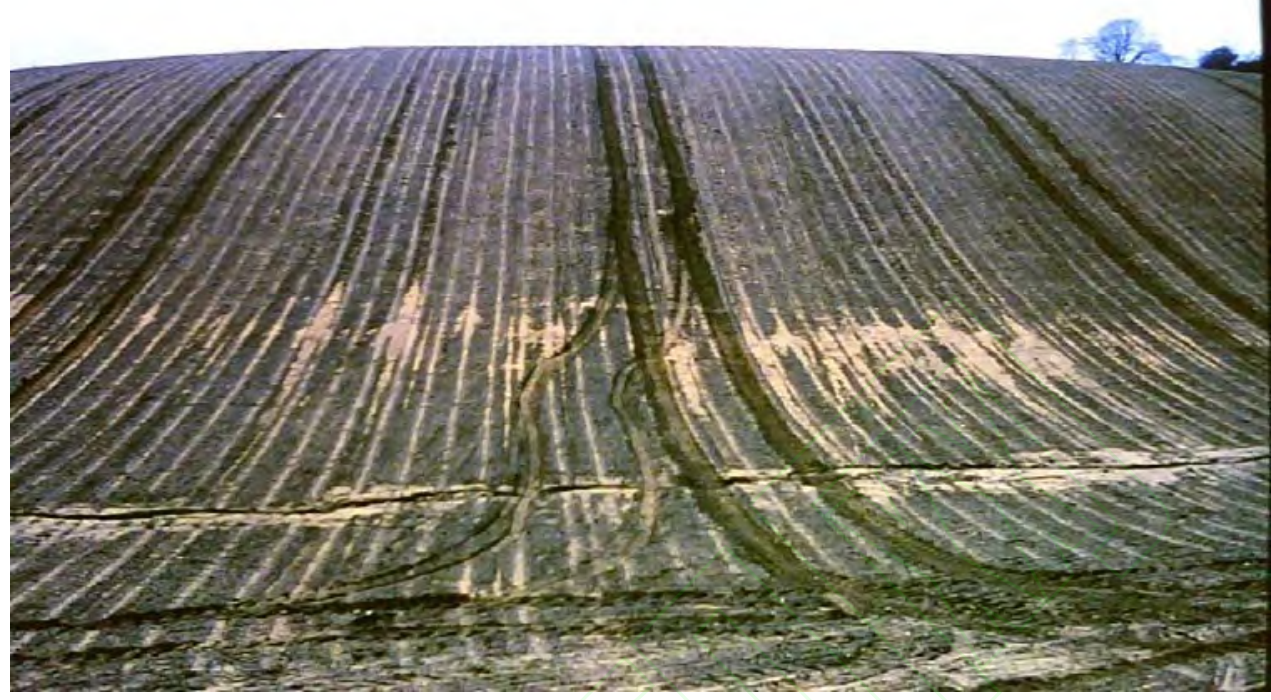

Fig. 5 Rill erosion along cultivation lines in east Shropshire, England, UK (photo by Michael Augustine Fullen).

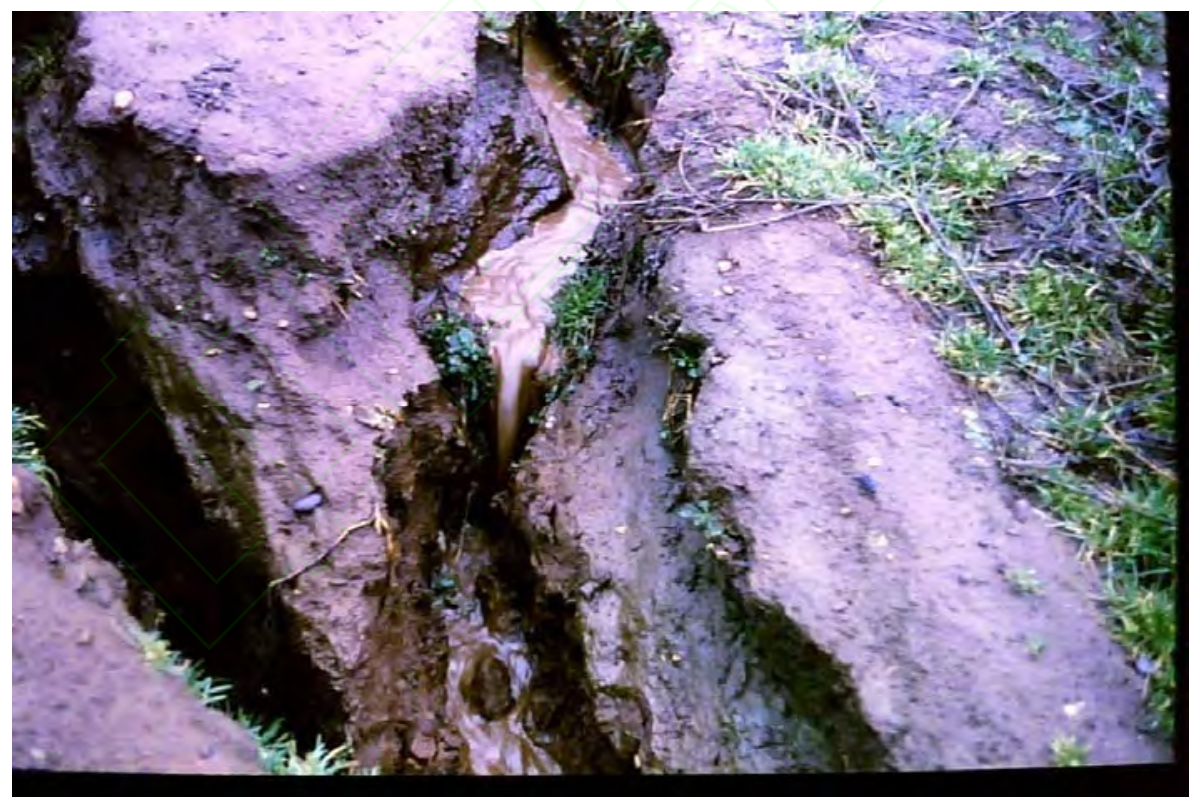

Fig. 6 Rill and gully erosion due to low intensity $(1.8 \mathrm{~mm} / \mathrm{h})$ rainfall on snowmelt saturated soils at Hilton, east Shropshire. Note the 'shoulder' at $20 \mathrm{~cm}$ depth, due to subsoil compaction (see Fullen, 1985; photo by Michael Augustine Fullen).

Geological soil erosion does not usually cause major environmental problems, because it takes place under natural conditions (i.e. without human disturbance), but accelerated soil erosion often does (Thornes, 1990; Gerrard, 1992; Selby, 1993; Morgan, 2005; Boardman, 2006; Boardman and Favis-Mortlock, 2013; Lopez-Vicente et al., 2013; Almagro and Martinez-Mena, 2014; Labriere et al., 2015). 


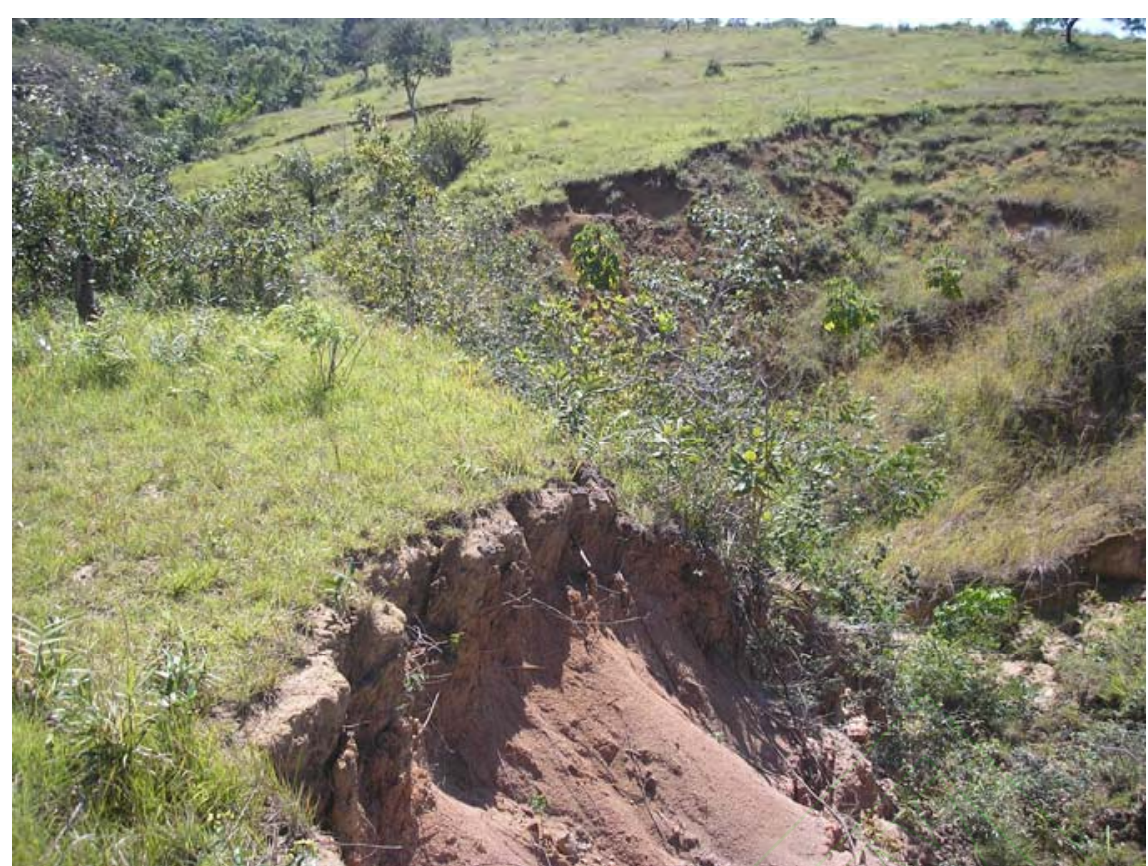

Fig. 7 Gully within Bacanga State Park, São Luis, Maranhão State, Brazil, in January 2015 (photo by José Fernando Rodrigues Bezerra).

The problems related to soil erosion are more evident when soil loss exceeds natural or geologic levels, usually due to the lack of soil conservation practises, which is called "accelerated erosion" (Selby, 1993). If we consider the Holocene, under natural vegetation cover, usually little soil erosion occurs. In most landscapes, while the vegetation is not removed, the export of matter occurs in the form of ions, with ground-water migrating into rivers, and then transferring to the sea. Vegetation might be removed naturally, by the ageing and dying of trees in forests, but this results in transfers of soil particles within distances of only several metres. Additional natural triggers are natural forest fires, from which one might expect a transfer of soil particles in the dimension of the specific slope. Severe climate changes (e.g. glaciation) might result in deforestation, triggering erosion processes, on a hemispheric to global scale. Earthquakes can also trigger local soil erosion. In addition, humans often clear forests for economic purposes (usually for agriculture or timber extraction), which encourages soil erosion, since precipitation and snow-melt can then produce runoff and, in turn, detach and transport soil particles. One could describe such erosion as 'Anthropocene soil erosion' (i.e. the human imprint on the global environment is now so active that it rivals some of the great forces of Nature in its impacts on the Earth system). In discussing the Holocene in Germany, Dreibrodt et al. (2010) commented "the comparison of the data from colluvial layers reflects the known settlement and land use history and testifies to the strong human impact on the geomorphologic system."

In the tropics, where rain-storms may be very intense, the signs of erosion are obvious, when the rivers become full of sediments, causing siltation (Selby, 1993; Fullen et al., 1995; Goudie and Viles, 1997; Ashman and Puri, 2002; Fullen and Catt, 2004; Morgan, 2005; Boardman and Poesen, 2006; Guerra et al., 2015; Labriere et al., 2015). Labriere et al. (2015) pointed out that "soil control is still provided in the humid tropics, to a certain extent, for crop and grass-dominated land uses, but is alarmingly depleted in bare soils, with dramatic consequences on soil loss." Even in temperate climatic zones, where heavy precipitation events are not usually as intense and concentrated as in the tropics, soil loss usually occurs at lower intensity, but also causes damage to agro-pastoral lands (Small and Clark, 1982; Abrahams, 1986; Parsons, 1988; Selby, 1993 ; Goudie, 
1990, 1995; Guerra, 1994; Goudie and Viles, 1997; Ashman and Puri, 2002; Fullen, 2003; Fullen and Catt, 2004; Morgan, 2005; Boardman and Poesen, 2006; Evans, 2006; Poesen et al., 2006; Plaza-Bonilla et al., 2013; Labirere et al., 2015). In addition, snow-melt, often over frozen and thus impermeable soil, can cause soil erosion in temperate zones.

Soil erosion also causes off-site problems, such as silting and pollution of areas where sediments are deposited, such as in rivers, reservoirs and lakes (Thornes, 1990; Wild, 1993; Goudie and Viles, 1997; Mosaddeghi et al., 2009; Boardman and Favis-Mortlock, 2013; Nacinovic et al., 2014; Guo, et al., 2015). According to Boardman and Favis-Mortlock (2013) "the period when the soil is inadequately protected represents a 'window of opportunity' for erosion. Thus, actual erosion in any year depends on: 1 . the timing, amount and intensity of rainfall in that year, 2. the start date and duration of the 'window of opportunity' and 3. the soil and morphological characteristics of the site."

The need for monitoring soil erosion with the use of experimental stations is very important, because through monitoring soil loss and runoff, erosion processes can be better understood. These important monitoring programmes produce short-term data (sometimes for decades). Rare events (extreme erosion-low frequency, high magnitude precipitation events) might not be measured within such temporal limitations. The data set could be extended immensely by the geomorphological study of historical soil erosion landscapes (Figs. 8 and 9). There are several ways to monitor and investigate soil erosion, in order to determine soil loss from fields and catchments. To do this, it is possible to use aerial photographs, over different months and/or years, to monitor rill and gully growth. When field and laboratory data are available, such as bulk density and the total eroded area, it is possible to calculate the amount of soil loss. This procedure is becoming more common, particularly when detailed scale aerial photographs are available. The use of remote sensing is another tool, which makes erosion studies more accurate and detailed, when combined with field and laboratory data. To achieve this aim, it is necessary to have good ground resolution, (i.e. $\leq 10 \mathrm{~m}$ ). According to Morgan (2005) "the studies of temporal changes in vegetation and soil conditions indicate that with further research it should be feasible to use remote sensing for continuous monitoring to identify in advance, when there is a high risk of erosion, so that appropriate protection measures can be implemented." In addition, depending on field conditions, monitoring programmes and laboratory analyses, it should be possible to accurately determine how much soil is being lost from a specific field and/or catchment area. 


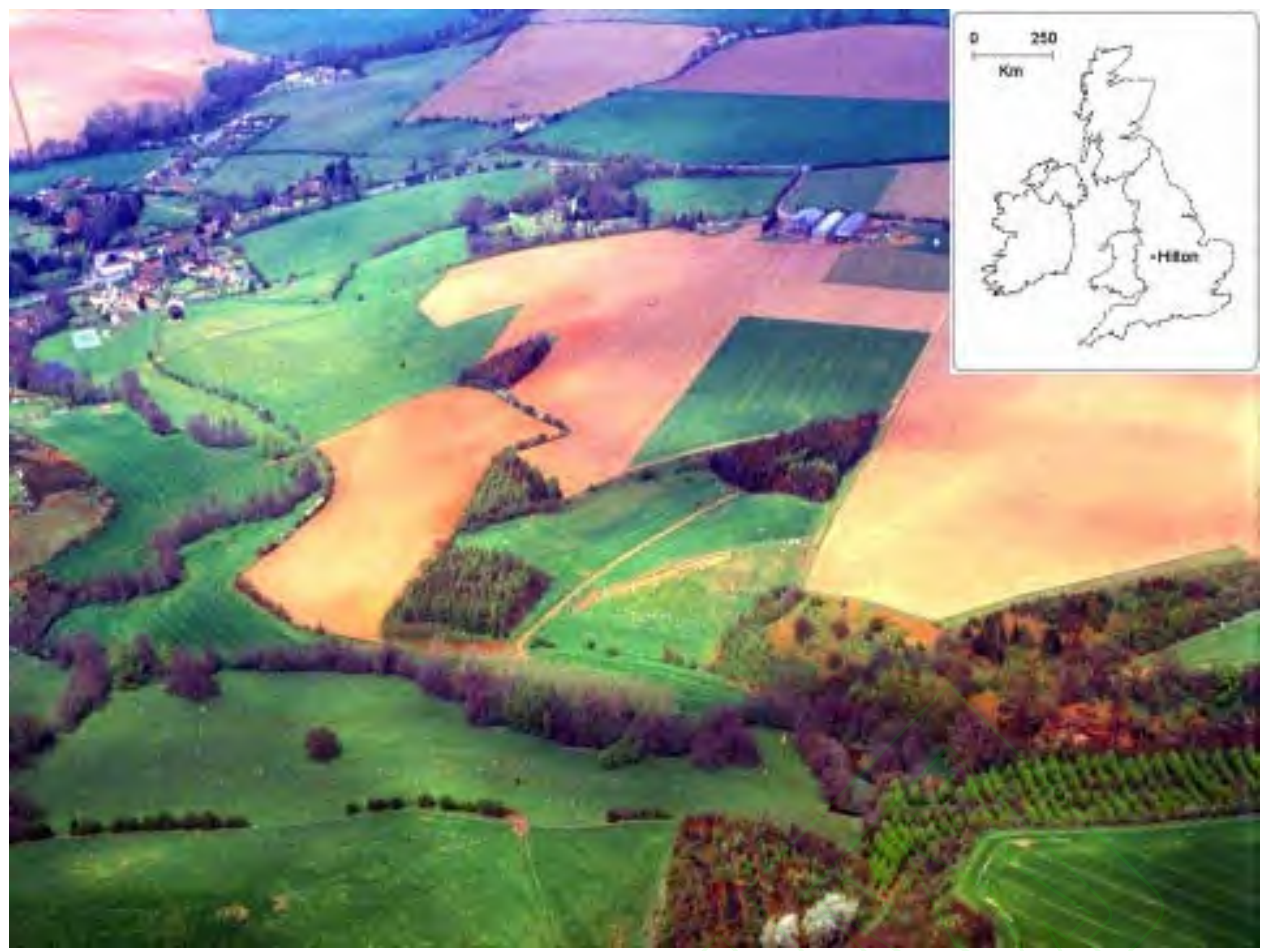

Fig. 8 Aerial view of the Hilton Experimental Site, East Shropshire, where soil loss and runoff have been monitored since 1982 (see Fullen, 1992; photo by Gill Barrett).

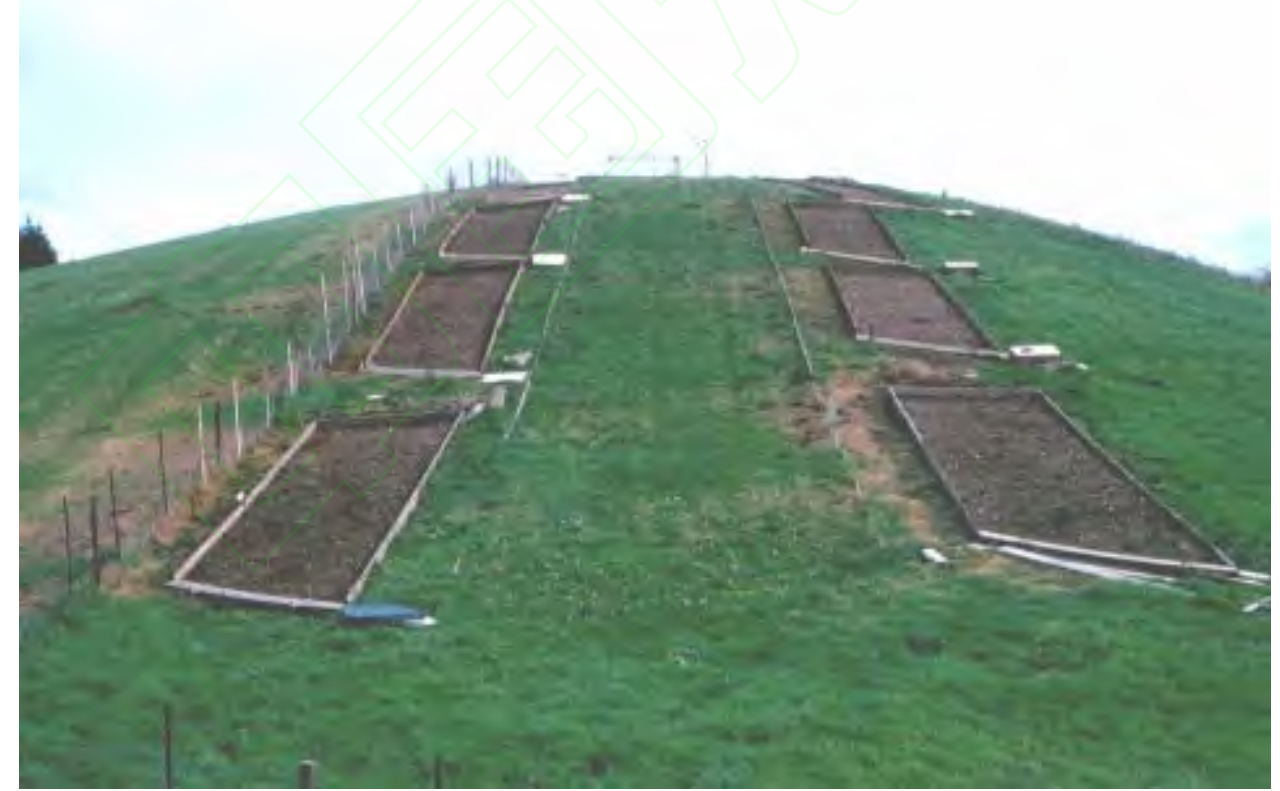

Fig. 9 Runoff plots at the Hilton Experimental Site (photo by Michael Augustine Fullen).

In 1960 the United States Department of Agriculture (USDA) established the maximum permissible value of 5 tonnes per ha per year of soil loss for the USA, which became known as the 'Tolerable value' (or T value) (Schertz, 1983). It is estimated that $\sim 80 \%$ of the world's agricultural soils are subject to some form of erosion (Ashman and Puri, 2002). On average, soils form at a rate of $\sim 1$ tonne per ha per year, and according to these authors, in Africa, Asia and South America, soil loss can exceed $30 \mathrm{t} / \mathrm{ha} / \mathrm{y}$. In Europe, where rains are not usually so intense, erosion rates can exceed 17 t/ha/y (Boardman and Poesen, 2006). 
Pressures on soils exerted by human activities is one of the main causes of erosion (Wild, 1993). The world population is large and growing, and totalled 7,401,421,170 according to the World Population Clock (12/02/2016). The exact world population is unknown; this is the best estimate we have, based on the integration of several demographic models. Moreover, people understandably aspire to higher living standards, placing yet more pressure on soil resources. These demographic processes require larger areas to cultivate, graze cattle and provide timber for fuel and construction. Together these activities clear permanent natural vegetation and expose soils to the erosive processes of wind and water. Although soil erosion occurs in different parts of the world, there is a difference between small fields, used by local farmers for subsistence agriculture, and the large fields of agro-industrial monocultures, since the latter usually use large connected fields. These often have poor soil structures and low soil organic matter contents, which produce much more runoff, and consequently, much more erosion. This is the Brazilian case, where these conditions produce total soil losses $>50 \mathrm{t} \mathrm{ha}^{-1} \mathrm{y}^{-1}$, and sometimes $>100 \mathrm{t} \mathrm{ha}^{-1} \mathrm{y}^{-1}$ (EMBRAPA, 2002; Guerra et al., 2014). Wild (1993) summarized the main causes of erosion:

1. Vegetation clearance, leaving soils unprotected.

2. Agriculture and cattle ranges, without conservation practises.

3. Cultivation and cattle ranges on slopes, sometimes $>45^{\circ}$, without conservation practises.

4. Trails caused by animals and humans, compacting soils and thus increasing surface water flow.

5. Highway construction, with inadequate environmental planning, which increases surface water flow and thus generates rills and gullies.

6. Different types of mineral quarries and other economic activities, leaving soils unprotected, and without proper rehabilitation, during and at the end of these activities.

Many authors agree with Wild (1993) (e.g. Selby, 1993: Goudie, 1995; Goudie and Viles, 1997; Favis-Mortlock and Guerra, 1999; Ashman and Puri, 2002; Fullen and Catt, 2004; Valentin et al., 2005; Evans, 2006; Morgan, 2005; Boardman, 2006; Boardman and Favis-Mortlock, 2013; Monsieurs et al., 2015).

Despite being a typical geomorphological process from rural areas, Guerra and Hoffmann (2006) outlined that for two Brazilian cities (São Luis, Maranhão State and Palmas, Tocantins State), although they were founded in different periods (São Luis was established in the $17^{\text {th }}$ Century and Palmas, in the $20^{\text {th }}$ Century), and "although they have different locations, histories and climates, both cities are experiencing an increasing problem of gully erosion, especially within the city limits" (Guerra and Hoffmann, 2006). This is due to similar factors, including vegetation clearance, lack of urban planning, inadequate rain and sewage systems and unpaved roads, especially on the city outskirts. This is agreed by several authors, who have discussed gully erosion within urban areas (e.g. Selby, 1993; Goudie and Viles, 1997; Favis-Mortlock and Guerra, 1999; Poesen, 2003; Morgan, 2005; Boardman, 2006; Evrard et al., 2010; Graeff et al., 2012; Monsieurs et al., 2015).

Besides the need to implement soil conservation practises (Mishra et al., 2015) to avoid damage to both the soil and environment, it is necessary to apply different techniques to recuperate soils once they become degraded (Fullen et al., 1995; Fullen and Catt, 2004; Bhattacharyya et al., 2009; De Baets et al., 2011; Fullen et al., 2011; Bhattacharyya et al., 2012; Dhital et al., 2013; Guerra et al., 2015). Some parts of the world produce the highest erosion rates due to soil mismanagement practises, such as slash and burn, and the absence of appropriate soil conservation techniques (e.g. terracing, contour cultivation and crop rotation) (Fullen and Catt, 2004; Morgan, 2005; Labriere et al., 2015). Consequently, long-term spatial variations in erosion occur in relation to changes in land cover, i.e. soil use and management. According to Bhattcharyya et al. (2012) "vegetation growth on 
problematic slopes often encounters problems, such as the absence of initial binding material in the soils prone to erosion by water."

Biological geotextiles constructed from different materials, such as Buriti (Mauritia flexuosa L.) in Brazil, are readily available in São Luis Municipality, and are simple and cost-effective to manufacture and provide immediate erosion control (Guerra et al., 2015) (Figs. 10 and 11). Most examples of soil recuperation are very localized and have short-term data. Hence, reports regarding long-term data are still needed, showing the effectiveness of land recuperation at the drainage basin scale (Kerr, 1998; Fullen and Catt, 2004; Morgan, 2005; Bhattacharyya et al., 2009, 2012; Guerra et al., 2014). Very good results have been obtained in São Luis using buriti leaves, which is a typical palm tree from Maranhão State, where the geotextiles plus vegetation cover have decreased runoff and erosion, consequently promoting water circulation within the soil profile (Guerra et al., 2015). The runoff which forms the gully is produced completely within the catchment area above the gully head, and on this specific site the catchment area is very small, because the local authorities have made major urban works to decrease this area. Consequently, little runoff is now generated. Therefore, the recuperation using buriti leaves has worked very well. Although there are many examples of soil recuperation, most of them are considered on a local scale and one has to also consider erosion on a global scale. Even considering soil erosion as a global problem of 'Anthropocene erosion,' local studies might contribute, in the long-term, to solving this problem, or at least to decreasing soil loss and promoting sustainable agriculture. This is the case of many countries, but "especially those where agricultural production is crucial to development and the majority of the rural people base their livelihood strategies on the primary sector" (Kerr, 1998). This is only one example of how geotextiles made from vegetal fibres can be used to recuperate eroded slopes. They are usually cheaper than synthetic geotextiles and generate income for impoverished local people. Soil erosion processes are influenced by many factors, including rainfall, soil properties, land-use and land management. Therefore, decreasing surface runoff in the catchment area (e.g. by increasing soil infiltration capacity and evapotranspiration rates), results from a permanent vegetation cover. Consequently, the fixation of gully walls is a real erosion mitigation action and, in many circumstances, it only attenuates the erosion processes. There are many conservation soil practises, including mulching, crop rotation systems, no-tillage agriculture, terracing and contour cultivation. Examples of effective soil conservation practises include:

1. Increased extent and density of vegetal cover.

2. Use of green manure (i.e. the addition and incorporation of undecomposed vegetal biomass on fallow soils).

3. Good soil management practises, particularly minimum tillage.

4. Maintaining cover on soils, especially retaining harvest residues on topsoils, thus adding organic matter to soil systems.

5. Improved cattle management systems and optimizing the combination of these systems with arable cropping systems to minimize soil erosion.

6. Re-afforestation and particular protection of riparian vegetation on erodible soils.

7. Contour cultivation. Experiments in Brazil have shown this can reduce runoff by $\leq 30 \%$ and soil loss by $\leq 50 \%$ (Bertoni and Lombardi Neto, 1990).

8. Vegetative buffers (strips of vegetation) in agricultural areas. These act as physical barriers to runoff and erosion and encourage infiltration.

9. Strips of stones, where stones in agricultural areas are placed in small channels dug parallel to contours, to impede surface water flow. 
10. Construction of small retention basins in small depressions, between areas of permanent agriculture.

All these conservation practises have promoted much more sustainable agriculture in several parts of the world, which improves soil drainage and simultaneously decreases soil erosion. Nevertheless, in many areas, soil degradation still occurs, due to the use of conventional agricultural systems and cattle ranching (Fullen and Catt, 2004; Morgan, 2005; Goudie and Boardman, 2010; Guerra et al., 2014).

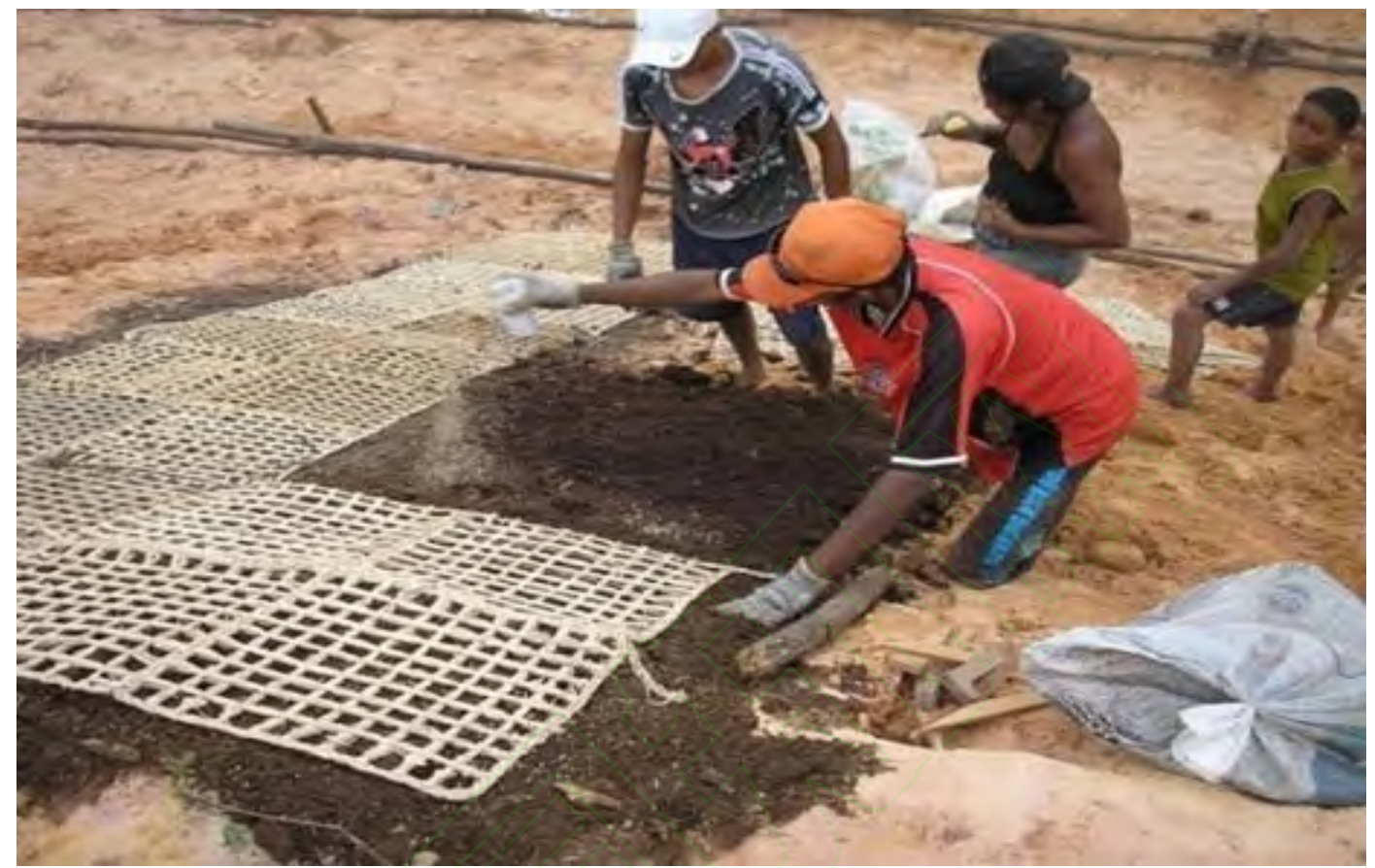

Fig. 10 Recuperation work in Sacavém gully, with the application of buriti geotextiles, manure and grass seeds, in São Luis City, Brazil, February 2008 (photo by José Fernando Rodrigues Bezerra).

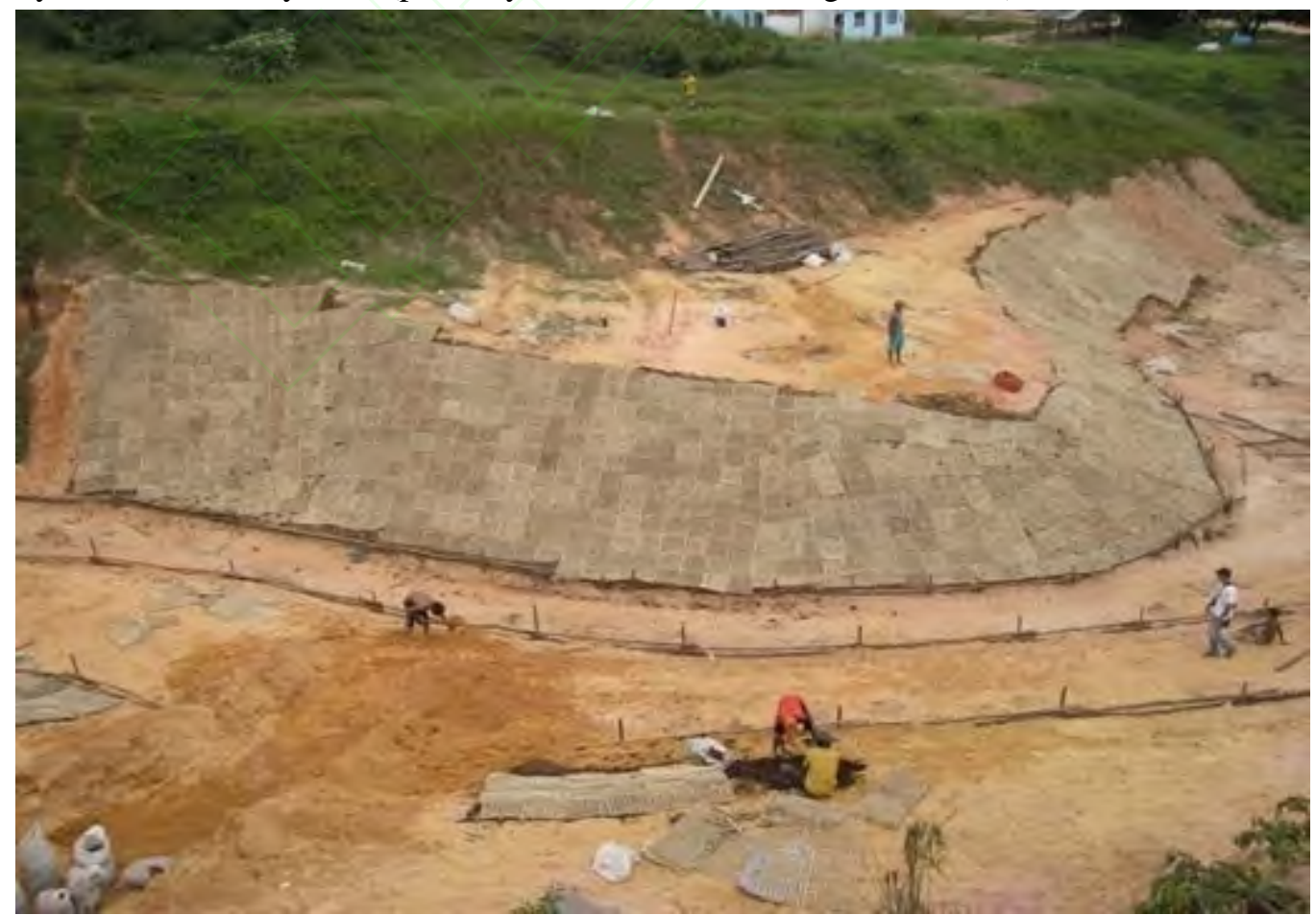

Fig. 11 Gully wall completely recuperated, after the application of buriti geotextiles, grass seeds, manure and nitrogen, phosphorus and potassium (NPK) fertilizers, February 2008 (photo by José Fernando Rodrigues Bezerra). 


\section{CONCLUSIONS}

Several aspects related to mass movements have been discussed, taking into account the role of the main environmental triggers, together with human actions on slopes. Such actions nearly always accelerate mass movements. The unplanned growth of cities is an important factor triggering mass movements. When this occurs often damage is severe and may even cause fatalities.

Soil erosion is another form of land degradation on slopes and both the factors which trigger its occurrence, together with its consequences, have been reviewed. Depending on the interactions of different erosion factors, including natural ones and soil use and management, different soil features appear on the soil surface, including sheet, rill and gully erosion. Although these erosion features tend to be more dramatic in the tropics, in recent decades they have also occurred in temperate morphoclimatic regimes. Wherever they occur, there is always damage and losses to agriculture and grazing land, with concomitant financial costs.

The Holocene encompasses the growth and impacts of the human species world-wide, including all written history, the development of major civilizations, and the overall significant transition toward urban living in the present. Human impacts on modern-era Earth and its ecosystems are considered to be of global significance for the future evolution of living species, including concomitant lithospheric or, more recently, atmospheric evidence of human impacts. Holocene mass movements and soil erosion are global problems, as they cause damage and deaths. These problems also they make life more difficult for millions of people, especially the poorest ones, who suffer most with the effects of catastrophic landslides, in urban areas and soil erosion in agricultural fields. According to Borgatti and Soldati (2010) "establishing links between climate and past landslides activity is indeed very difficult. This is primarily due to the few records of landslide events (imprecise dates, incomplete databases) dating back to the last century, to the Little Ice Age and to the Holocene."

Both mass movements and soil erosion, although two different forms of land degradation, usually cause severe forms of environmental damage and material loss and even injury and death. Both cause on-site and off-site effects, causing problems to where they occur (the export zone) and to places of deposition (import zone). The distance between export and import zones can be many kilometres. Preventive ways of handling these very destructive geomorphological processes is always the best way to address them (i.e. 'prevention is better than cure'). When preventing soil erosion and mass movements, one has to also consider the role of climate change, with most predictions suggesting more intense and extreme rainfall. Together with population growth, this "can drastically increase landslides and soil erosion, especially in developing countries, where both population and agricultural pressure on land resources often lead to exploitation of unstable slopes" (Borgatti and Soldati, 2010). Nevertheless, once such environmental damage occurs, it is possible to recuperate affected areas. The use of geotextiles has been adopted in many countries, such as in Brazil, using fibres sourced from indigenous vegetation and local labour and knowledge. This has potential as a sustainable way of tackling the problems of degraded areas.

\section{ACKNOWLEDGEMENTS}

The authors acknowledge the financial support of the Brazilian Research Council (CNPq). 


\section{REFERENCES}

Abrahams, A D. 1986. Hillslope Processes. Allen and Unwin, London, 416pp.

Agnihotri P, Kumar A. 2015. Green House gas emissions and climate change: Options to mitigate climate change. American Journal of Pharmacy \& Health Research 3: 54-59.

Almagro, M, Martinez-Mena, M. 2014. Litter decomposition rates of manure as affected by soil erosion, transport and deposition processes, and the implications for the soil carbon balance of a rainfed olive grove, under a dry Mediterranean climate. Agriculture, Ecosystems and Environment. 196: 167-176.

Arbuckle J G, Morton L W., Hobbs J. 2013. Climate change beliefs, and perceived risk and mitigation: The roles of trust in sources of climate information, Understanding farmer perspectives on climate change adaptation. Environment and Behavior. 15: 1-30.

Ashman M R, Puri G. 2002. Essential Soil Science - A Clear and Concise Introduction to Soil Science. Blackwell Publishers, Oxford, 198pp.

Bertoni J, Lombardi Neto F. 1990. Conservação dos Solos. São Paulo, Icone. 355pp.

Bhattacharyya R, Fullen M A, Davies K., Booth C A. 2009. Utilizing palm-leaf geotextile mats to conserve loamy sand soil in the United Kingdom. Agriculture, Ecosystems and Environment. 130: 50-58.

Bhattacharyya R, Smets T, Fullen M A, Poesen J, Booth C A. 2010. Effectiveness of geotextiles in reducing runoff and soil loss: A synthesis. Catena. 80: 184-195.

Bhattacharyya R, Fullen M A, Booth C A, Guerra, A J T, Mendonça J K S, Guerra T T, Sathler R, Bezerra J F R, Mendes S P. 2011. Effectiveness of biological geotextiles on soil and water conservation in different agroenvironments. Land Degradation \& Development. 22: 1-9.

Bhattacharyya R, Zheng Y, Yongmei L, Tang Li, Panomtaranichagul M, Peukrai S, Thud D C, Cuong T H, Toan T T, Jankauskas B, Jankauskiene G, Fullen M A, Subedi M, Booth C A. 2012. Effects of biological geotextiles on aboveground biomass production in selected agro-systems. Field Crops Research. 126: 23-36.

Boardman J. 2006. Soil erosion science: reflections on the limitations of current approaches. Catena. 68: 73-86.

Boardman J, Verstraeten G, Bielders C. 2006. Muddy floods. In Boardman J, Poesen J (eds.) Soil Erosion in Europe. Wiley, Chichester. pp. 743-755.

Boardman J, Poesen J. 2006. Soil Erosion in Europe: Major Processes, Causes and Consequences. In: Boardman J, Poesen J. (eds.) Soil Erosion in Europe. Wiley, Chichester. pp. 209-218.

Boardman J, Vandaele K. 2010. Soil erosion, muddy floods and the need for institutional memory. Area. 42: 502513.

Boardman J, Favis-Mortlock D T. 2013. The significance of drilling date and crop cover with reference to soil erosion by water, with implications for mitigating erosion on agricultural land in South East England. Soil Use and Management. 29: 1-8.

Bochet E, Poesen J, Rubio J L. 2006. Runoff and soil loss under individual plants of a semi-arid Mediterranean shrubland: influence of plant morphology and rainfall intensity. Earth Surface Processes and Landforms. 31: 536-549.

Borgatti L, Soldati M. 2010. Landslides and climate change. Soil erosion. In: Alcántara-Ayala, I Goudie A. (eds). Geomorphological Hazards and Disaster Prevention. Cambridge University Press, Cambridge. pp. 87-95.

Bork HR. 1989. The history of soil erosion in southern Lower Saxony. Landschaftgenese und Landschaftsokologie. 16: 135-163.

Brunetti M T, Guzzetti F, Cardinali M, Fiorucci F, Santangelo Mancinelli P, Komatsu G, Borselli L. 2014. Analysis of a new geomorphological inventory of landslides in Valles Martineris, Mars. Earth and Planetary Science Letters. 405: 156-168.

Brunsden D. 1988. Slope instability, planning and geomorphology in the United Kingdom. In: Hooke J M. (ed.) Geomorphology in Environmental Planning. John Wiley, Chichester. pp. 105-119.

Cendrero A, Dramis F. 2006. The contribution of landslides to landscape evolution in Europe. Geomorphology. 15: 191-211.

Clague J J, Robert N J. 2012. Landslide hazard and risk. In Clague J, Stead D. (eds.) Landslides: Types, Mechanisms and Modelling. Cambridge University Press, Cambridge. pp. 1-9. 
Coelho Netto A L, Avelar A S, Fernandes M C, Lacerda W A. 2007. Landslide susceptibility in a mountainous geoecosystem, Tijuca Massif, Rio de Janeiro: the role of morphometric subdivision of the terrain. Geomorphology. 87: 120-131.

CRED (Centre for Research on the Epidemiology of Disasters). 2011. EM-DAT: The OFDA/CRED International Disaster Database. Université Catholique de Louvain, Centre for Research on the Epidemiology of Disasters [available at www.emdat.be/, accessed 12 February 2016].

Crozier M J, Glade T. 2005. Landslides hazard and risk: issues, concepts and approach. In Glade T, Anderson M. and Crozier M. (eds) Landslide Hazard and Risk. John Wiley, New York. pp. 1-41.

Cruden D M, Varnes, D J. 1996. Landslide types and processes. In Turner, A K, Schuster R L. (eds.), Landslides, Investigation and Mitigation: Transportation Research Board (Special Report 247). US National Research Council, Washington, DC. pp. 36-75.

De Baets S, Poesen J, Meersmans J, Serlet L. 2011. Cover crops and their erosion-reducing effects during concentrated flow erosion. Catena. 85: 237-244.

Dhital Y P, Kayastha R B, Shi J. 2013. Soil bioengineering application and practices in Nepal. Environmental Management. 51: 354-364.

Dotterweich M. 2009. The history of soil erosion and fluvial deposits in small catchments of central Europe: Deciphering the long-term interaction between humans and the environment - A review. Geomorphology. 101: 192-208.

Dreibrodt S, Lubosa C, Terhorstb B, Dammc H, Borka H R. 2010. Historical soil erosion by water in Germany: Scales and archives, chronology, research perspectives. Quaternary International, 222, 80-95.

Dreibrodt S, Wiethold J. 2015. Lake Belau and its catchment (northern Germany): A key archive of environmental history in northern central Europe since the onset of agriculture. The Holocene, 1-27.

Eeckhaut M V D, Poesen J, Vandekerckhove L, Gils M V, Rompaey A V 2010. Human-environment interactions in residential areas susceptible to landsliding: the Flemish Ardennes case study. Area. 42: 339-358.

Ellis S, Mellor A. 1995. Soil and Environment. Routledge, London, 287pp.

EMBRAPA. 2002. Uso agrícola dos solos brasileiros. Embrapa Solos, Rio de Janeiro, Brazil, 174pp.

Enters T. 1998. A framework for the economic assessment of soil erosion and soil conservation. In: Penning de Fries F W T, Augs F, Kerr J. (eds). Soil Erosion at Multiple Scales - Principles and Methods for Assessing Causes and Impacts. CABI Publishing, Oxford. pp. 1-20.

Evans R. 1993. Sensitivity of the British Landscape to Erosion. In Thomas D S G, Allison, R J (eds) Landscape Sensitivity. John Wiley, New York. pp. 189-210.

Evans R. 2006. Curtailing water erosion of cultivated land: an example from North Norfolk, eastern England. Earth Surface Processes and Landforms. 31: 598-605.

Evrard O, Heitz C, Lie'geois M, Boardman J, Vandaele K, Auzet A V, Van Wesemael B. 2010. A comparison of management approaches to control muddy floods in Central Belgium, Northern France and Southern England. Land Degradation \& Development. 21: 322-335.

Favis-Mortlock D T, Guerra A J T (1999) The implications of general circulation model estimates of rainfall for future erosion: a case study from Brazil. Catena. 37: 329-354.

Fell R, Stapledon D, McGregor P. (2012). Landslides and geologic environments. In Clague J, Stead, D. (eds.) Landslides: Types, Mechanisms and Modelling. Cambridge University Press, Cambridge. pp. 134-144.

Ferreira C J, Silva P C F, Furlan S A, Brollo M J, Tominaga L K, Vedovello R, Guedes A C M, Ferreira D F, Eduardo A S, Sobrinho J M A, Lopes E A, Cripps J A, Perez F A, Rocha G R. 2005. Revising strategies for reclamation of derelict sites due to mining of residual soil in Ubatuba, north of São Paulo State: the views and roles of the stakeholders. Sociedade e Natureza, Special Issue, 643-660.

Fullen M A. 1985. Compaction, hydrological processes and soil erosion on loamy sands in east Shropshire, England. Soil \& Tillage Research. 6: 17-29.

Fullen M A. 1992. Erosion rates on bare loamy sand soils in East Shropshire, UK. Soil Use and Management. 8: 157-162.

Fullen, M A. 2003. Soil erosion and conservation in Northern Europe. Progress in Physical Geography 27(3): 331-358.

Fullen M A, Fearnehough W, Mitchell D J, Trueman I C. 1995. Desert reclamation using Yellow River irrigation water in Ningxia, China. Soil Use and Management 11: 77-83. 
Fullen M A, Catt J A. 2004. Soil Management: Problems and Solutions. Edward Arnold, London, 269pp.

Fullen M A, Subedi M, Booth C A, Sarsby R W, Davies K, Bhattacharyya R, Kugan R, Luckhurst D A, Chan K, Black A W, Townrow D, James T, Poesen J, Smets T, Kertész A., Tóth A, Szalai Z, Jakab G, Jankauskas B, Bühmann C, Paterson G, Mulibana E, Nell J P, Guerra A J T, Mendonça J K S, Guerra T T, Sathler R, Bezerra J F R, Peres S M, Zheng Y, Tang L, Peukrai S, Thu D C, Kuong T H, Toan T T, Sylva J Z, Cole A, Dearlove M, Corkill C, Tomlinson P. 2011. Utilizing biological geotextiles: Introduction to the BORASSUS Project and global perspectives. Land Degradation and Development. 22: 453-462.

Gerrard J. 1992. Soil Geomorphology: An Integration of Pedology and Geomorphology. Chapman and Hall, London, 269pp.

Goudie A. 1990. The Human Impact on the Natural Environment. Blackwell, Oxford, 388pp.

Goudie A. 1995. The Changing Earth - Rates of Geomorphological Processes. Blackwell, Oxford, 302pp.

Goudie A, Viles H. 1997. The Earth Transformed: An Introduction to Human Impacts on the Environment. Blackwell, Oxford, 276pp.

Goudie A S, Boardman J. 2010. Soil erosion. In Alcántara-Ayala I, Goudie A. (eds) Geomorphological Hazards and Disaster Prevention. Cambridge University Press, Cambridge. pp. 177-188.

Graeff O, Guerra A J T, Jorge M C O. 2012. Catastrophic floods and landslides in Brazil. Geography Review. 26: 38-41.

Griffiths J S, Whitworth M. 2012. Engineering geomorphology of landslides. In Clague J, Stead D. (eds.) Landslides: Types, Mechanisms and Modelling. Cambridge University Press, Cambridge. pp. 10-23.

Guerra A J T. 1994. The effect of organic matter content on soil in simulated rainfall experiments in West Sussex, UK. Soil Use and Management. 10: 60-64.

Guerra A J T, Hoffmann H. 2006. Urban gully erosion in Brazil. Geography Review. 19: 26-29.

Guerra A J T, Oliveira A, Oliveira F L, Gonçalves L F H. 2007. Mass movements in Petrópolis, Brazil. Geography Review. 20: 34-37.

Guerra A J T, Jorge M C O. 2009. Mapping hazard risk - A case study of Ubatuba, Brazil. Geography Review. 22: 11-13.

Guerra A J T, Soares da Silva A. 2011. Predicting soil loss and runoff from forest roads and seasonal cropping systems in Brazil, using WEPP. In Morgan R P C, Nearing M A. (eds.) Handbook of Erosion Modelling. Blackwell, Oxford. pp. 186-194.

Guerra A J T, Bezerra J F R, Jorge M C O, Fullen M A. 2014. The geomorphology of Angra dos Reis and Paraty Municipalities, Southern Rio de Janeiro State. Revista Geonorte. 9: 1-21.

Guerra A J T, Jorge M C O. 2014. Hazard risk assessment: a case study from Brazil. Geography Review. 27: 1215.

Guerra A J T, Fullen M A, Jorge M C O, Alexandre S T. 2014. Soil erosion and conservation in Brazil. Anuário do Instituto de Geocências. UFRJ. 37: 81-91.

Guerra A J T, Bezerra, J F R, Fullen, M A, Mendonça, J K S, Jorge, M C O. 2015. The effects of biological geotextiles on gully stabilization in São Luís, Brazil. Natural Hazards. 75: 2625-2636.

Gumiere S J, Le Bissonnais Y, Raclot D. 2009. Soil resistance to interrill erosion: Model parameterization and sensitivity. Catena. 77: 274-28.

Guo Q, Hao Y, Liu B. 2015. Rates of soil erosion in China: A study based on runoff plot data. Catena. 124: 68-76.

Gurgel S P P, Bezerra F H R, Correa A C B, Marques F O, Maia R P. 2013. Cenozoic uplift and erosion of structural landforms in NE Brazil. Geomorphology. 186: 68-84.

Guzzetti F, Mondini, A C, Cardinali M, Fiorucci F, Santangelo M, Chang K T. 2012. Landslide inventory maps: new tools for an old problem. Earth Science Reviews. 112: 42-66.

Hansen M J. 1984. Strategies for classification of landslides. In Brunsden D, Prior D. (eds.) Slope Instability. John Wiley, Chichester. pp. 1-25.

Hart M G. 1986. Geomorphology - Pure and Applied. Allen and Unwin Publishers, London, 228pp.

Hasset J J, Banwart W L. 1992. Soils and their Environment. Prentice Hall, New Jersey, 424pp.

Hooke J M. 1988. Geomorphology in Environmental Planning. John Wiley, Chichester, 274pp.

Kanungo D P, Sharmas S. 2014. Rainfall thresholds for prediction of shallow landslides around ChamoliJoshimath Region, Garhwal Himalayas, India. Landslides. 11: 629-638. 
Kerr J. 1998. The Economics of Soil Degradation: From National Policy to Farmers' Fields. In Penning de Fries F W T, Augs F, Kerr J. (eds.) Soil Erosion at Multiple Scales - Principles and Methods for Assessing Causes and Impacts. CABI Publishing, Oxford. pp. 21-38.

Kitutu M G., Muwanga A, Poesen J, Deckers J A. 2009. Influence of soil properties on landslide occurrences in Bududa District, Eastern Uganda. African Journal of Agricultural Research. 4: 611-620.

Korup O. 2012. Landslides in the Earth system. In Clague J, Stead, D. (eds.) Landslides: Types, Mechanisms and Modeling. Cambridge University Press, Cambridge. pp. 10-23.

Izac A M N, Swift M J. 1994. On agricultural sustainability and its measurement in small-scale farming in SubSaharan Africa. Ecological Economics. 11: 105-125.

Labriere N, Locatelli B, Laumonier Y, Freycon V, Bernoux M. 2015. Soil erosion in the humid tropics: A systematic quantitative review. Agriculture, Ecosystems and Environment. 203: 127-139.

Lascelles B, Favis-Mortlock D T, Parsons J, Guerra A J T. 2000. Spatial and temporal variation in two rainfall simulators: implications for spatially explicit simulation experiments. Earth Surface Processes and Landforms. 25: 709-721.

Lin J C, Petley D, Jen C H, Koh A, Hsu M L. 2006. Slope movements in a dynamic environment - A case study of Tachia, Central Taiwan. Quaternary International. 147: 103-112.

Liu M Y, Chang Q R, Qi Y B, Liu J, Chen T. 2014. Aggregation and soil organic carbon fractions under different land uses on the tableland of the Loess Plateau of China. Catena. 115: 19-28.

López-Vicente M, Poesen J, Navas A, Gaspar L. 2013. Predicting runoff and sediment connectivity and soil erosion by water for different land use scenarios in the Spanish Pre-Pyrenees. Catena. 71: 62-73.

Mendes, R M, Valério Filho, M. 2015. Real-time monitoring of climatic and geotechnical variables during landslides on the slopes of Serra do Mar and Serra da Mantiqueira (São Paulo State, Brazil). Engineering. 7: 140-159.

Mishra A K, Aggarwal P, Bhattacharyya R, Das T K, Sharma A R, Singh R. 2015. Least limiting water range for two conservation agriculture cropping systems in India. Soil \& Tillage Research. 150: 43-56.

Monsieurs E, Dessie M, Adgo E, Poesen J, Deckers J, Verhoest N, Nyssen J. 2015. Seasonal surface drainage of sloping farmland: a review of its hydrogeomorphic impacts. Land Degradation and Development. 26: 35-44.

Morgan R P C. 2005. Soil Erosion and Conservation. Blackwell, Oxford, 304pp.

Mosaddeghi M R, Mahboubi A A, Safadoust A. 2009. Short-term effects of tillage and manure on some soil physical properties and maize root growth in a sandy loam soil in western Iran. Soil \& Tillage Research. 104: 173-179.

Nacinovic M G, Mahler C F, Avelar A S. 2014. Soil erosion as a function of different agricultural land uses in Rio de Janeiro. Soil \& Tillage Research. 144: 164-173.

Nadal-Romero E, Petrlick K, Verachtert E, Bochet E, Poesen J. 2014. Effects of slope angle and aspect on plant cover and species richness in a humid Mediterranean badland. Earth Surface Processes and Landforms. 39: 1705-1716.

Oluwagbenga O, Orimoogunje I. 2014. Forest cover change and land use dynamics in Oluwa Forest Reserve, southwestern Nigeria. Journal of Landscape Ecology. 7: 25-44.

Parsons A J. 1988. Hillslope Form. Routledge, New York, 212pp.

Petley D J. 1984. Ground investigation, sampling and testing for studies of slope instability. In Brunsden D, Prior, D. (eds.) Slope Instability. John Wiley, Chichester. pp. 67-101.

Petruci O, Pasqua A A, Polemio M. (2013) Impact of damaging geo-hydrological events and population development in Calabria, Southern Italy. Water. 5: 1780-1796.

Plaza-Bonilla D, Cantero-Martinez C, Vinas P, Álvarofuentes J. 2013. Soil aggregation and organic carbon protection in a no-tillage chronosequence under Mediterranean conditions. Geoderma. 193: 76-82.

Poesen J, Nachtergaele J, Verstraeten G, Valentin C. 2003. Gully erosion and environmental change: importance and research needs. Catena. 50: 91-133.

Poesen J, Vanwalleghem T, De Vente J, Knapen A, Verstraeten G, Martınez-Casasnovas J A. 2006. Gully erosion in Europe. In Boardman J, Poesen J. (eds.) Soil Erosion in Europe. John Wiley, Chichester. pp. 515-536.

Rodrigues S C, Bezerra J F R. 2010. Study of matric potential and geotextiles applied to degraded soil recovery, Uberlândia (MG), Brazil. Environ Earth Science. 60:1281-1289.

Selby M J. 1993. Hillslope Materials and Processes. $2^{\text {nd }}$ edition, Oxford University Press, Oxford, 451pp. 
Sensoy H, Kara O. 2014. Slope shape effect on runoff and soil erosion under natural rainfall conditions. Biogeosciences and Forestry. 7: 110-114.

Shafiq F, Ahsan K, Nadeem A, Sarim M, Shaikh A B, Siddiq M. 2014. Role of ICT in climate change monitoring: A review study of ICT based Climate Change Monitoring Services. Research Journal of Recent Sciences. 3: 123-130.

Schertz D L. 1983. The basis for soil loss tolerances. Journal of Soil and Water Conservation. 38:10-14.

Shukla M K, Lal R, Ebinger M. 2006. Determining soil quality indicators by factor analysis. Soil \& Tillage Research. 87: 194-204.

Silva D G, Correa A C B, Santos W O, Nóbrega P R C. 2005. Sedimentological characterization of the pedological cover of Camaçari Ecological Reservation, Cabo de Santo Agostinho, PE, Northeastern Brazil. Sociedade e Natureza, Uberlandia, Special Issue: 512-521.

Small R J, Clark M J. 1982. Slopes and Weathering. Cambridge University Press, Cambridge, 112pp.

Souza C R G, Suguio K. 2003. The coastal erosion risk zoning and the State of São Paulo Plan for coastal management. Journal of Coastal Research. 35: 530-547.

Subedi M, Hocking T J, Fullen M A, McCrea A R, Milne E, Wu Bo-Zhi, Mitchell D J. 2009. Use of farmers' indicators to evaluate the sustainability of cropping systems on sloping land in Yunnan Province, China. Pedosphere. 19: 344-355.

Subedi M, Fullen M A, Booth C A, Thu D C, Cuong T H, Toan T T, Jonsyn-Ellis F, Cole A, Guerra A J T, Bezerra J F R, Zheng Yi, Li Yongmei, Tang Li, Bühmann C, Paterson D G. 2012. Contribution of biogeotextiles to soil conservation and socioeconomic development. Outlook on Agriculture. 41: 187-194.

Sun W, Shao Q, Liu J, Zhai J. 2014. Assessing the effects of land use and topography on soil erosion on the Loess Plateau in China. Catena. 121: 151-163.

Thomas D S G, Allison R J. 1993. The sensitivity of landscapes. In Thomas D S G, Allison R J. (eds.) Landscape Sensitivity. John Wiley, Chichester. pp. 1-12.

Thornes J B. 1990. The interaction of erosional and vegetational dynamics in land degradation: spatial outcomes. In Thornes J B. (ed.) Vegetation and Erosion, Processes and Environments. Wiley, Chichester. pp. 41-53.

Tiffen M, Mortimore M, Gichuki F. 1994. More People, Less Erosion: Environmental Recovery in Kenya. John Wiley, Chichester, 235pp.

Trudgill S T. 1988. Soil and Vegetation Systems. Oxford University Press, Oxford, 211pp.

Valentin C, Poesen J, Yong L. 2005. Gully erosion: impacts, factors and control. Catena. 63: 132-153.

Van Beek, Cammeraat E., Andreu V, Mickovski S B, Dorren L. 2008. Hillslope Processes: Mass Wasting, Slope Stability and Erosion. In Norris J E, Stokes A, Mickovski S B, Cammeraat E, van Beek R, Nicoll B C, Achim A. (eds.) Slope Stability and Erosion Control: Ecotechnological Solutions. Slope Stability and Erosion Control. Springer, Amsterdam. pp. 17-64.

Vanmaercke M, Maetens W M, Poesen J, Jankauskas B, Jankauskiene G, Verstraeten G, Vente J. 2012. A comparison of measured catchment sediment yields with measured and predicted hillslope erosion rates in Europe. Journal Soils Sediments. 12: 586-602.

Vanmaercke M, Poesen J, Mele B V, Demuzere M, Bruynseels A, Golosov V, Bezerra J F R., Bolysov S, Dvinskih A, Frankl A, Fuseina Y, Guerra A J T, Haregeweyn N, Ionita I, Imwangana F M, Moeyersons J, Moshe I, Saman A N, Niacsu L, Nyssen J, Otsuki Y, Radoane M, Rysin I, Ryzhov Y V, Yermolaev O. 2016. How fast do gully headcuts retreat? Earth-Science Reviews. 154: 336-355.

VanWesten C J, Castellanos Abella E A, Sekhar L K. 2008. Spatial data for landslide susceptibility, hazards and vulnerability assessment: an overview. Engineering Geology. 102: 112-131.

Varnes D J. 1978. Slope movements: types and processes. In Schuster R L, Krizek R J. (eds.) Landslide Analysis and Control. Transportation Research Board Special Report, National Academy of Sciences, Washington DC. 176: $11-33$

Vente J, Verduyn R, Verstraeten G, Vanmaercke M, Poesen J. 2011. Factors controlling sediment yield at the catchment scale in NW Mediterranean geoecosystems. Journal Soils Sediments. 11: 690-707.

Wild A. 1993. Soils and the Environment - An Introduction. Cambridge University Press, Cambridge 287pp.

World Population Clock: http://www.worldometers.info/world-population/ [accessed 12/02/2016]. 